Article

\title{
Active Bionanocomposite Coating Quality Assessments of Some Cucumber Properties with Some Diverse Applications during Storage Condition by Chitosan, Nano Titanium Oxide Crystals, and Sodium Tripolyphosphate
}

\author{
Mahmoud Helal ${ }^{1}$, Rokayya Sami ${ }^{2, *(D)}$, Eman Algarni ${ }^{2}$, Garsa Alshehry ${ }^{2}$, Huda Aljumayi ${ }^{2}$, Amina A. \\ M. Al-Mushhin ${ }^{3}$, Nada Benajiba ${ }^{4}$, Murthy Chavali ${ }^{5}$, Nishant Kumar ${ }^{6}{ }^{10}$, Abdullah Iqbal ${ }^{7}$, Salman Aloufi ${ }^{8}$, \\ Amal Alyamani ${ }^{8}$ D, Nawal Madkhali ${ }^{9}$ and Abeer Almasoudi ${ }^{10}$
}

check for

updates

Citation: Helal, M.; Sami, R.; Algarni,

E.; Alshehry, G.; Aljumayi, H.; Al-Mushhin, A.A.M.; Benajiba, N.; Chavali, M.; Kumar, N.; Iqbal, A.; et al. Active Bionanocomposite Coating Quality Assessments of Some Cucumber Properties with Some Diverse Applications during Storage Condition by Chitosan, Nano Titanium Oxide Crystals, and Sodium Tripolyphosphate. Crystals 2022, 12, 131. https://doi.org/ $10.3390 /$ cryst 12020131

Academic Editors: Assem Barakat and Alexander S. Novikov

Received: 31 December 2021

Accepted: 15 January 2022

Published: 18 January 2022

Publisher's Note: MDPI stays neutral with regard to jurisdictional claims in published maps and institutional affiliations.

Copyright: (c) 2022 by the authors. Licensee MDPI, Basel, Switzerland. This article is an open access article distributed under the terms and conditions of the Creative Commons Attribution (CC BY) license (https:/ / creativecommons.org/licenses/by/ $4.0 /)$.
1 Department of Mechanical Engineering, Faculty of Engineering, Taif University, P.O. Box 11099, Taif 21944, Saudi Arabia; mo.helal@tu.edu.sa

2 Department of Food Science and Nutrition, College of Sciences, Taif University, P.O. Box 11099, Taif 21944, Saudi Arabia; eman1400@tu.edu.sa (E.A.); garsa.a@tu.edu.sa (G.A.); huda.a@tu.edu.sa (H.A.)

3 Department of Biology, College of Science and Humanities in Al-Kharj, Prince Sattam Bin Abdulaziz University, Al-Kharj 11942, Saudi Arabia; a.almushhin@psau.edu.sa

4 Department of Basic Health Sciences, Deanship of Preparatory Year, Princess Nourah bint Abdulrahman University, P.O. Box 84428, Riyadh 11671, Saudi Arabia; nabenajiba@pnu.edu.sa

5 Office of the Dean (Research) and Division of Chemistry, Department of Science, Faculty of Science \& Technology, Alliance University, Chandapura-Anekal Main Road, Bengaluru 562106, Karnataka, India; ChavaliM@gmail.com

6 Department of Food Science and Technology, National Institute of Food Technology Entrepreneurship \& Management, Plot No. 97, Sector 56, HSIIDC, Industrial Estate, Kundli, Sonipat 131028, Haryana, India; nishant.kumar@niftem.ac.in

7 Department of Food Technology and Rural Industries, Bangladesh Agricultural University, Mymensingh 2202, Bangladesh; iqbal21155@bau.edu.bd

8 Department of Biotechnology, College Sciences, Taif University, P.O. Box 11099, Taif 21944, Saudi Arabia; s.aloufi@tu.edu.sa (S.A.); a.yamani@tu.edu.sa (A.A.)

9 Department of Physics, College of Sciences, Imam Mohammad Ibn Saud Islamic University (IMISU), Riyadh 11623, Saudi Arabia; namadkhali@imamu.edu.sa

10 Food Science Department, College of Science, Branch of the College at Turbah, Taif University, Taif 21944, Saudi Arabia; a.sleman@tu.edu.sa

* Correspondence: rokayya.d@tu.edu.sa 
Keywords: active bionanocomposite; application; coating; cucumber; quality; shelf-life; storage

\section{Introduction}

Cucumber (Cucumissativus L.) is one of the essential seasonal vegetable crops globaly and a favourite commodity export for markets and local consumptions. It represents one of the greatest vital and financial vegetables in many countries and especially Saudi Arabia [1]. Cucumber belongs to the Cucurbitaceae family and has great nutritional and medicinal functions, especially in diabetic patients, due to the useful ingredients such as $95 \%$ moisture, $3.6 \%$ carbohydrate, $0.65 \%$ proteins, $1.3 \mathrm{mg} \mathrm{kg}^{-1}$ magnesium, as well as vitamins B5 $\left(0.026 \mathrm{mg} \mathrm{kg}^{-1}\right)$ and ascorbic acid $\left(0.28 \mathrm{mg} \mathrm{kg}^{-1}\right)$ [2]. Cucumber is cultivated and consumed as a fresh vegetable, sliced in salads during all seasons, and as pickles before the ripening phase [3]. Cucumbers are consumed worldwide due to their brittle flavor, nutrients, and health benefits. They have a short shelf-life ofabout 14 days, being perishable due to the high moisture content [4]. Cucumbers are influenced by respiration, moisture loss, yellowing, firmness, barrier, optical, mechanical changes, physiological injuries, shrivelling, and microbial growth during handling and storage processes [5]. The color can depend on the level of maturity [6] and chlorophyll degradation [7] as a result of the metabolic processes [8]. The customer judges the quality according to several sensorial factors such as firmness, appearance [9], and other related chemical properties such as vitamin C content and total soluble solids [10]. Storage can increasesome biological activities such as growth of the bacteria, molds, and yeasts [11]. Moreover, several studies reported that stored cucumbers have been associated with some microbial contaminations such as Salmonella, being contaminated during post-harvest processes [12,13]. Recent techniques have included mild heat treatments, cold-shock temperature, essential oils, and atmospheric conditions; conversely, they lead to decline several physiological and sensorial characterizes [14].

Chitosan and nano chitosan areseafood by-products purchased from crab, shrimp, and crawfish, and can act as a barrier to the migrationof moisture and gases, by reducing the oxidation of nutrients, delaying the senescence symptoms, and improving the visual and tactile features [15]. Moreover, coatings with high aloe vera gel, methoxy pectins, cassava starch, xanthan gum, glycerol, edible films, and nano-coatings are applied for several products in the food industry [16].

Several research papers $[17,18]$ have indicated that coatings are significant in preventing cross-contaminations. Most uncoated cucumber samples in retail markets have lost moisture, appearance, and other sensorial evaluations during storage [19]. Therefore, long-term preservation methods are required to avoid spoilage sothat cucumbermight be consumed in off-seasons as well [20-22]. The titanium dioxide nanoparticles-chitosan composite has excellent photocatalytic activity against the organic pollutants, while chitosan has been reported to have antibacterial activities. In addition, the combination ofnano titanium oxide crystals and chitosan has enhanced the mechanical properties of the formed films [23]. Sodium tripolyphosphate can be used as a crosslinker to stabilize the nanoparticle polymers in the nanoparticle formations [24].

The present research work aimed to determine active bionanocomposite coating quality assessments (using chitosan, nano titanium oxide crystals, and sodium tripolyphosphate) of some cucumber properties, such as color index profile, skin toughness, crispness index, reducing sugars, and total sugars, with the addition of the antimicrobial contamination against Salmonella spp., with some diverse applications during storage during the chilling condition for 21 days at $10^{\circ} \mathrm{C}$.

\section{Materials and Methods}

\subsection{Materials}

Fresh cucumber samples in the winter season were transferred from an orchard (Alhada, Taif, Saudi Arabia) in 2020/2021. The substances were chitosan, derived from the $85 \%$ 
deacetylation of chitin, which can be found in some fungi and seashells, nano $\mathrm{TiO}_{2}$ crystals (VK-T25Q; $\mathrm{TiO}_{2}-30 \mathrm{~nm}$ with purity more than $99 \mathrm{wt} \%$ ), and sodium tripolyphosphate, Formula: $\mathrm{Na}_{5} \mathrm{P}_{3} \mathrm{O}_{10}$ with ISO Purity of 90 99\%), all obtained from Chengdu Dova, The New Material Co., Shanghai, China.

\subsection{Preparation of Coating Solutions}

Chitosan $(\mathrm{CH})$ solution with $1 \%$ concentration was prepared by dissolving in acetic acid solution after adjusting the $\mathrm{pH}$ to reach (5.0) with buffer solution, and then the solutions were made to be $(1.5 \mathrm{~L})$ with sonicating overnight at $>20 \mathrm{kHz}$. Chitosan-nano titanium oxide crystals (CH-Nano) solution was prepared by dispersing with $1 \%$ concentration of $\mathrm{TiO}_{2}$ nanoparticles in $0.5 \mathrm{~L}$ of $\mathrm{CH}$ solution with constant stirring for $6 \mathrm{~h}$. (CH-Nano-ST) solution was prepared by dispersing $2 \%$ of sodium tripolyphosphate in $0.5 \mathrm{~L}$ of $\mathrm{CH}$ solution with stirring as described in the previous research by Khojah et al. [24].

\subsection{Coating Processes}

Cucumber samples were sorted for uniform size and no sign of any physical or mechanical damage or even fungus infection. Cucumber samples were washed with tap water to remove any loose soil, then with calcium hypochlorite (2\%) for $15 \mathrm{~min}$, and fan-dried at room temperature.

The cucumber fruits were randomly distributed into four groups:

- $\quad$ The first group (Control) was coated with distilled water as untreated samples (control).

- The second group $(\mathrm{CH})$ was coated with chitosan.

- The third group (CH-Nano) was coated with a combination of chitosan and nano titanium oxide crystals.

- The fourth group (CH-Nano-ST) was coated with a combination of chitosan, nano titanium oxide crystals, and sodium tripolyphosphate as a crosslinker among nanoparticle polymers. Figure 1 presents the formulations, coating application on cucumber samples, and quality evaluation and shelf-life extension.

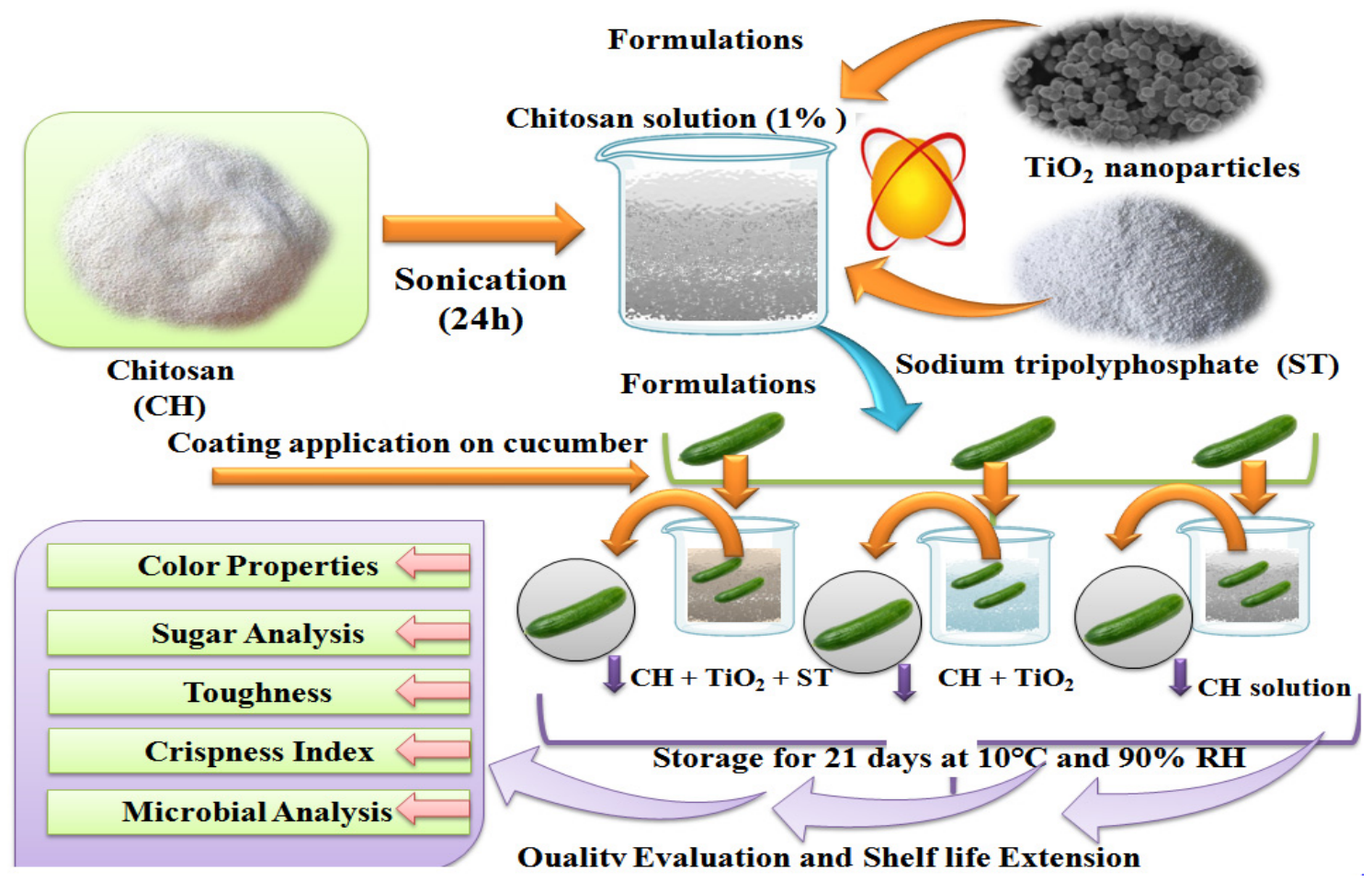

Figure 1. Formulations, coating application on cucumber samples, quality evaluation, and shelf-life extension. 


\subsection{Coating Applications}

Cucumber samples were dipped in the distilled water and coating solutions for $10 \mathrm{~s}$, the excess solutions were drained, and (coated and control) cucumber samples were air-dried. After drying, they were chilled in plastic trays with perforations at $10{ }^{\circ} \mathrm{C}$ and $90 \%$ relative humidity. At regular intervals of seven days, the cucumber samples were removed and evaluated for quality parameters until 21 days of the storage period. Three replicates were applied for each treatment, while each replicate included five cucumber fruits [24].

\subsection{Color Index Profile}

The color parameters of cucumber samples were evaluated by using the Miniscan XE Plus (Hunter \& Associates Laboratory, Hunter Lab, Reston, VA, USA) spectrophotometer that provided changes in $L^{*}, a^{*}$, and $b^{*}$ color space values $[25,26]$. The reflectance spectra were carried out in triplicate for three equatorial opposite sides of the cucumber surfaces $(n=9)$, then the final average of $L^{*}, a^{*}$, and $b^{*}$ values were obtained for each treatment every 7 days.

\subsection{Reducing Sugar and Total Sugar Analysis}

The reducing and total sugars from cucumber samples of each group were triplicatedand evaluated using a UV-Vis spectrophotometer (Max M2, San Jose, CA, USA) [27-29]. An aliquot of freeze-dried samples in liquid $\mathrm{N}_{2}$ was refluxed with $100 \mathrm{~mL}$ alkaline solution of copper salt, boiling for $30 \mathrm{~min}$ [30]. Next, the titration method was applied witha protein-free solution in the presence of methylene blue for reducing sugar analysis, while total sugar analysis was evaluated after the inversion with concentrated hydrochloric acid.

\subsection{Toughness, Crispness Indexes Evaluation}

The physical attributes of cucumber texture such as toughness and crispness indexes were evaluated at regular intervals of seven days until 21 days of storage period [31]. The toughness of every treatment was evaluated using a texture profile unit (TPU-2S, Yamaden Co., Tokyo, Japan) with a $3 \mathrm{~mm}$ plunger moving at $150 \mathrm{~mm} \mathrm{~min}^{-1}$. The crispness index was achieved from the force distance curves for the samples [32].

\subsection{Evaluation of Antimicrobial Contamination}

Antimicrobial contamination analyses were achieved in vivo according to Jung and Schaffner [13]. Approximately $2 \mathrm{~mL}$ of 20X PBS (phosphate-buffered saline), pH 7.4, was added to lab blender bags (Seward Stomacher 400, Seward Stomacher, West Sussex, UK), each containing $10 \mathrm{~g}$ cucumber. Serial dilutions were made $\left(10^{-1}, 10^{-2}\right.$, and $\left.10^{-3}\right)$ in PBS, and $0.1 \mathrm{~mL}$ of each dilution was plated on the surface of the selective media Hektoen enteric agar (Difco, BD, Fisher Scientific, Hampton, NH, USA) with $50 \mu \mathrm{g} / \mathrm{mL}$ nalidixic acid. The plates were incubated at $\left( \pm 37^{\circ} \mathrm{C}\right)$ for $24 \mathrm{~h}$ for Salmonella spp. growth. Results were enumerated as $\log$ CFU/g (colony-forming unit)/grams of cucumbers) [33].

\subsection{Statistical Analysis}

The experimental data and results were analyzed by a multifactor analysis of variance (ANOVA), while the significance of differences between treatments was carried out using Tukey's range test at $p<0.01$.

\section{Results}

\subsection{Color Properties}

Color is one of the significant signs of cucumber quality and influences customer acceptance during storage [34]. On the day of preparation, the lightest treatment was $\mathrm{CH}$ followed by CH-Nano-ST and CH-Nano, while at the end of 21 days, CH-Nano remained the lightest with 44.38 and CH-Nano-ST was a little darker (43.73) than the others, which had some signs of spoilage and aging on cucumbers; Figure 2a. As presented in Figure 2b, discoloration was detected in all treatments due to the transformation of chlorophyll into carotenoids. The discoloration was extra severe with control 22.3, which started to spoil 
after the end of the first week. After the 14th day, in $\mathrm{CH}$ samples, a little higher value of $b^{*}$ (value 25.31) was detected, then it had some signs of spoilage, demonstrating a color difference, compared with those coated with nano-materials. Chitosan coatings have been applied by several researchers to delay color change [35,36].CH-Nano and CH-NanoST treatments had the lowest values after 21 days of the storage period, 22.19 and 30.3, respectively. In terms of greenness $a^{*}$ value, $\mathrm{CH}-\mathrm{Nano}-\mathrm{ST}$ retained the maximum greenness (-7.99) compared to $\mathrm{CH}-\mathrm{Nano}$ samples, which recorded -7.31; Figure 2c. Overall, coating with nano-materials promoted the preservative properties and inhibited yellowing in the peel of cucumber samples. That may be due to the ability of chitosan and nano titanium oxide crystals to retard the degradation of chlorophyll by slowing metabolism in the cucumber peel [24]. Nano titanium oxide crystals reduced the conversion of chlorophyll to yellow-olive-colored pheophytin [37].

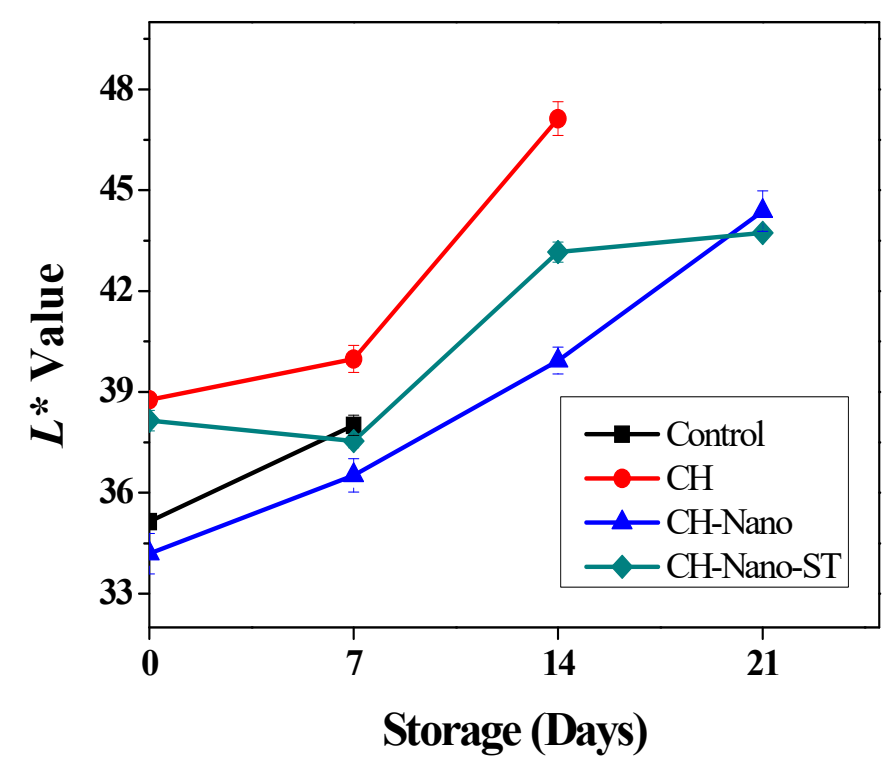

(a)

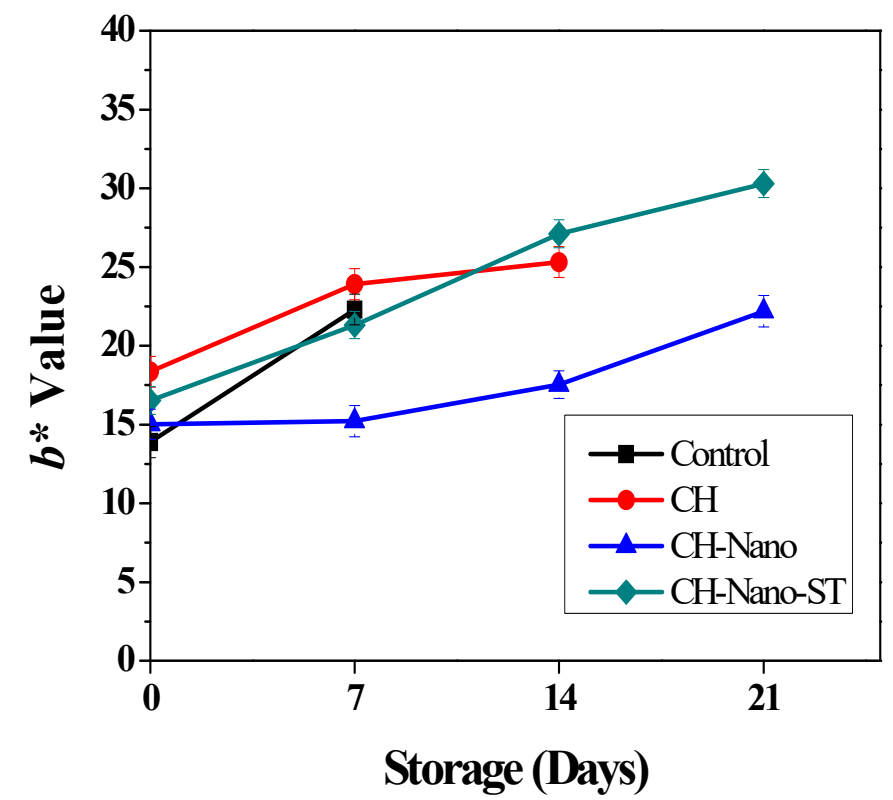

(b)

Figure 2. Cont. 


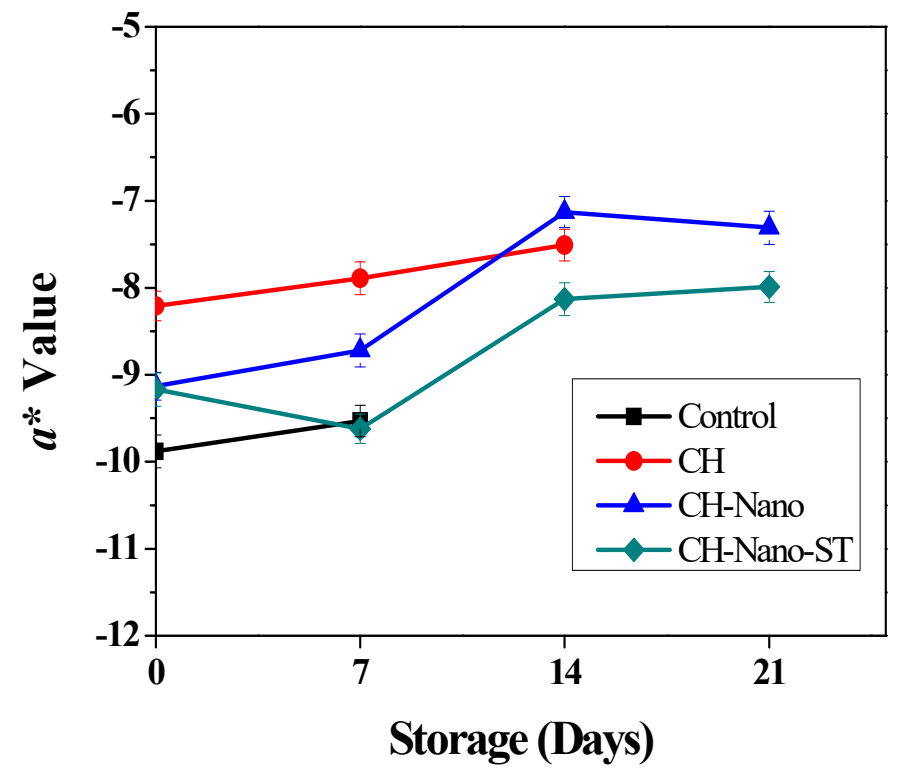

(c)

Figure 2. Effect of coating treatments of cucumber sampleson color index profile; (a) $L^{*}$ value, (b) $a^{*}$ value, and (c) $b^{*}$ value.

\subsection{Sugar Analysis}

The rate of change of reducing sugars and total sugars of cucumber samples stored for three weeks at $10^{\circ} \mathrm{C}$ is presented in Figure $3 \mathrm{a}, \mathrm{b}$. Control and $\mathrm{CH}$ samples were soiled after the 7 th and the 21st days of the whole storage, respectively. After 21 days of the storage period, the reducing sugar content reduced to reach $-0.64 \mathrm{~g} / 100 \mathrm{~g}$ and $-0.21 \mathrm{~g} / 100 \mathrm{~g}$ for $\mathrm{CH}-\mathrm{Nano}$ and $\mathrm{CH}-\mathrm{Nano}-\mathrm{ST}$ treatments, respectively. Parallel changes were detected in total sugar contents, which reached $-0.66 \mathrm{~g} / 100 \mathrm{~g}$ and $-0.26 \mathrm{~g} / 100 \mathrm{~g}$ for $\mathrm{CH}-\mathrm{Nanoand}$ $\mathrm{CH}-\mathrm{Nano}-\mathrm{ST}$ treatments, respectively. The presence of sugar in the stored cucumbers is a vital index due to its benefit for health [24,38].

The sugar analysis for cucumbers was affected by distilled water, $\mathrm{CH}, \mathrm{CH}-\mathrm{Nano}$, and $\mathrm{CH}-\mathrm{Nano}-\mathrm{ST}$ interactions, which decreased with increasing the storage period. However, providing nano-coating with the addition of sodium tripolyphosphate may preserve the cucumbers' sugar analysis, alleviate the adverse effects, and lead to a desirable quality of cucumber samples during storage. Sugar is utilized as a substrate and energy source for respiratory metabolism. Zapotoczn and Markowski [32] reported that a higher sugar content meant a better quality was preserved of cucumber samples during storage.

\subsection{Texture Properties}

The texture properties such as toughness and crispness indexes of treated cucumber samples during storage at $10^{\circ} \mathrm{C}$ are presented in Figure $4 \mathrm{a}, \mathrm{b}$. The CH-Nano-ST treatment presented a lower value of 1.05 for toughness, followed by $\mathrm{CH}-\mathrm{Nano}(1.13 \%)$ at the end of the storage period. Cucumbers with $\mathrm{CH}$ treatment had the toughest skin $(0.93 \%)$ after the 14th day, followed by CH-Nano (0.32\%); Figure 4a. Control samples showed the highest toughness value on the seventh day of storage, with signs of ageing and spoilage from then until the end of the storage period. Generally, CH-Nano-ST treatment positively affected the cucumber texture, which had softer and extra tender skin. 


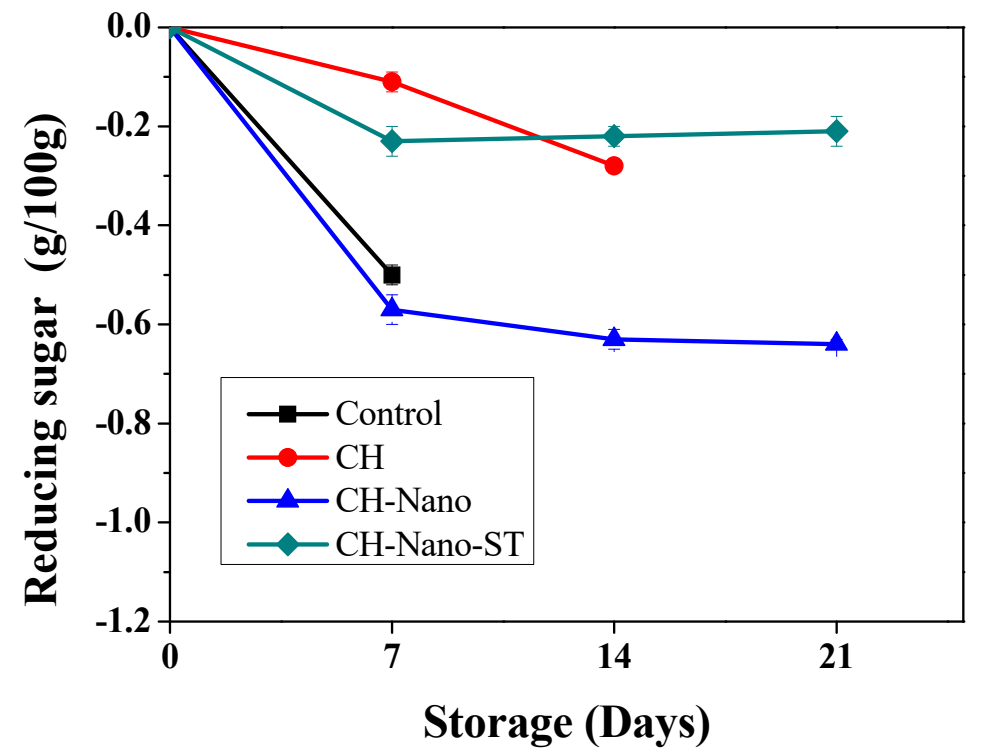

(a)

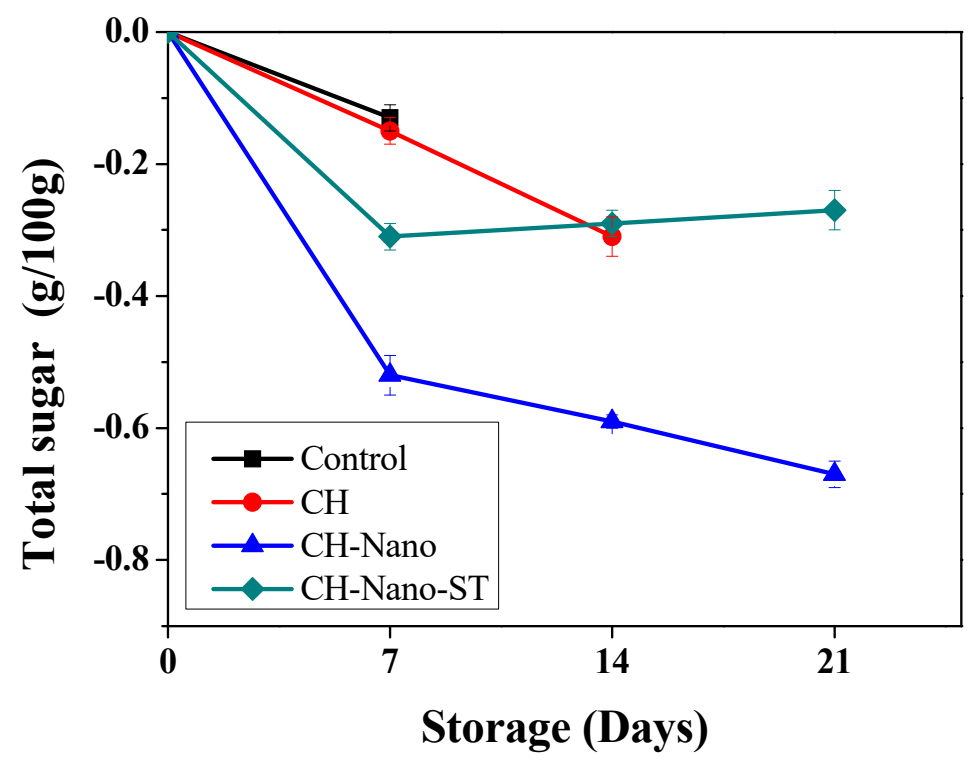

(b)

Figure 3. Effect of coating treatments of cucumber sampleson reducing sugar (a), and total sugar contents (b).

Moreover, the highest crispness index was detected for cucumbers with $\mathrm{CH}-\mathrm{Nano}$ $(5.12 \%)$ at the end of the storage period, while those treated with CH-Nano-ST treatment had a slight decline to reach $4.92 \%$. The crispness index of cucumbers with $\mathrm{CH}$ treatment was clarified and increased with the storage period until 14 days to reach $4.65 \%$, then theyhad some signs of spoilage. The crispness index value on control was distinctly observed and raised with the period of storage to reach $4.12 \%$ on the seventh day, becoming approximately spoiled at 14 days. Slight distinct influences on the physical properties of cucumber samples were detected under the $\mathrm{CH}-\mathrm{Nano}-\mathrm{ST}$ treatment. There were no clear differences for $\mathrm{CH}-\mathrm{Nano}$ cucumbers compared with controland $\mathrm{CH}$ samples due to the limitation of samples that spoiled and had less desirable texture, juicy and even firm and crisp after 7 and 14 days, respectively. Nakamachi et al. [39] reported that loss can be due to some biological, chemical, or functionalchanges on tissues during storage. The 
current study was in agreement with earlier studies, which showed a decrease in physical properties as the storage period proceeded [40].

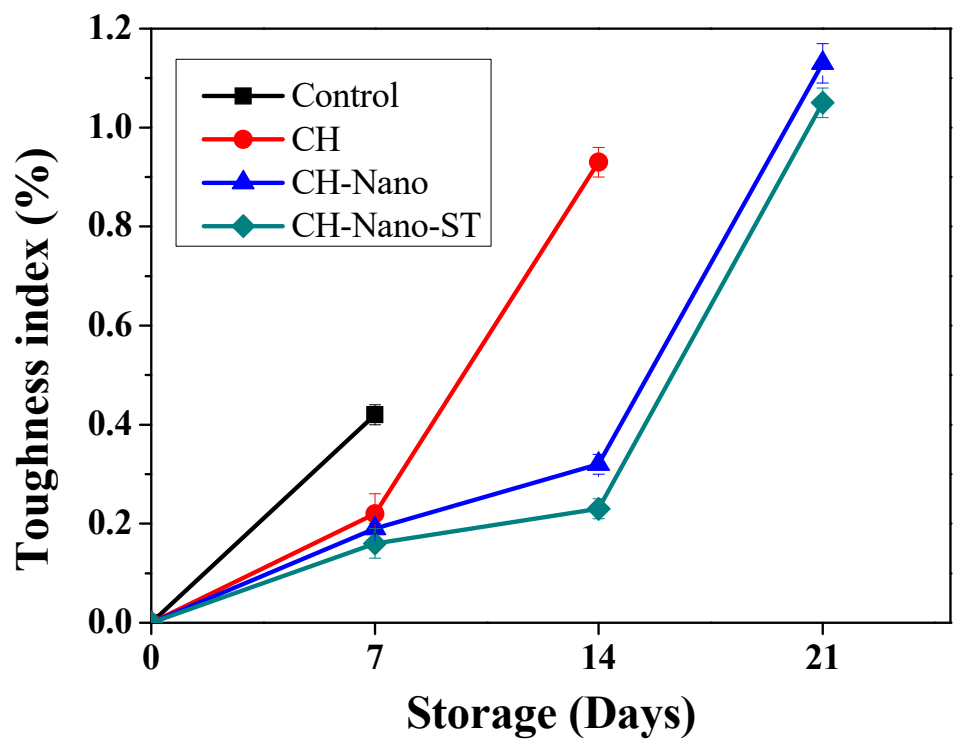

(a)

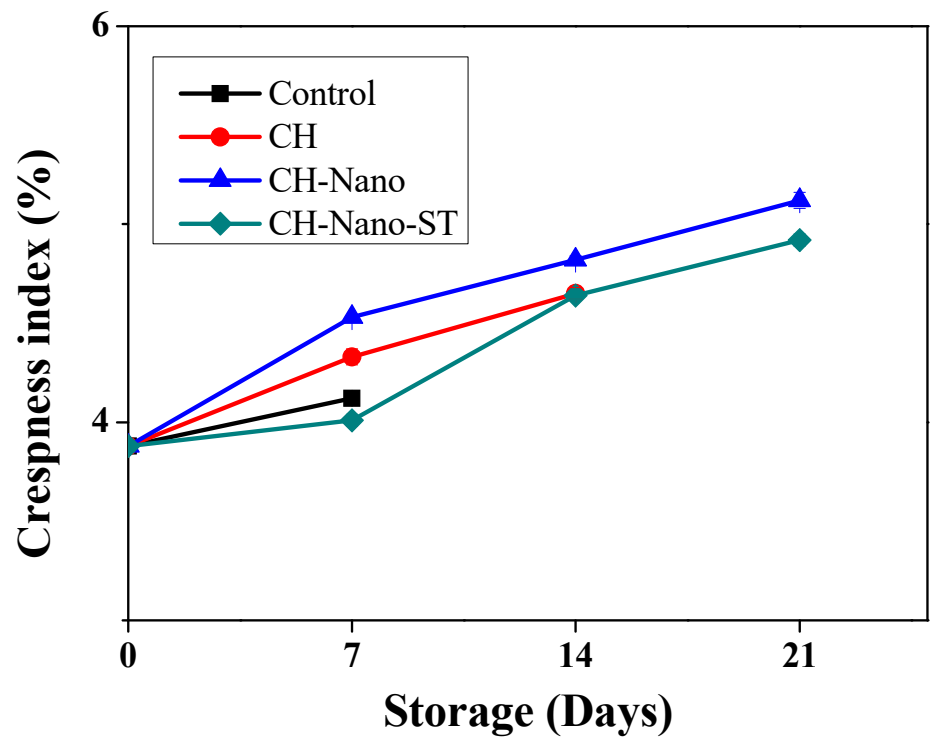

(b)

Figure 4. Effect of coating treatments of cucumber sampleson texture properties; toughness indexes (a), and crispness index (b).

\subsection{Antimicrobial Contamination Analyses}

As a result of the antimicrobial contamination analyses in cucumbers, Salmonella was detected as $0.79 \log \mathrm{CFU} / \mathrm{g}$ on the preparation day. On the other hand, $\mathrm{CH}$ samples clarified $1.12 \log \mathrm{CFU} / \mathrm{g}$ on the 14th day of the storage period (Table 1). The results were in agreement with the work of Hara-Kudo et al. [41], who detected that the Salmonella spp. growth in cucumbers during storage reached 0.1-0.2 log CFU/g, which can lead to infections in humans. 
Table 1. Bacterial contamination of Salmonella spp. isolated from coated cucumber samples during storage at $10{ }^{\circ} \mathrm{C}$.

\begin{tabular}{ccccc}
\hline Storage (Days) & Control & CH & CH-Nano & CH-Nano-ST \\
\hline 0 & $0.79 \pm 0.02^{\mathrm{a}}$ & $0.79 \pm 0.03^{\mathrm{a}}$ & $0.79 \pm 0.02^{\mathrm{b}}$ & $0.79 \pm 0.04^{\mathrm{d}}$ \\
7 & $0.88 \pm 0.01^{\mathrm{b}}$ & $0.93 \pm 0.02^{\mathrm{b}}$ & $0.81 \pm 0.04^{\mathrm{c}}$ & $0.80 \pm 0.05^{\mathrm{c}}$ \\
14 & & $1.12 \pm 0.04^{\mathrm{c}}$ & $0.86 \pm 0.01^{\mathrm{c}}$ & $0.81 \pm 0.03^{\mathrm{b}}$ \\
21 & & & $1.09 \pm 0.05^{\mathrm{a}}$ & $0.94 \pm 0.08^{\mathrm{a}}$ \\
\hline
\end{tabular}

Notes: ${ }^{\mathrm{a}-\mathrm{d}}$ : means within the same column with different superscript letters are significantly different at $p<0.01$.

The results indicated that $\mathrm{CH}-\mathrm{Nano}-\mathrm{ST}$ treatment can be applied to delay the microbial contamination of Salmonella spp. in cucumbers as it reached $0.94 \log \mathrm{CFU} / \mathrm{g}$ at the end of the storage period. Moreover, $\mathrm{CH}-\mathrm{Nano}$ treatment also delayed the Salmonella spp. growth to reach $1.09 \log \mathrm{CFU} / \mathrm{g}$. In a word, Salmonella spp. was detected during the storage of cucumber samples; however, coating with nano-materials and sodium tripolyphosphate as a cross-linker delayed the bacterial generations. The pathogens may infect customers, possibly causing demanding conditions to treat the infection due to their antibiotic resistance [42,43]. Consequently, nano-coating treatments with the addition of sodium tripolyphosphate can be applied to regulate Salmonella spp. in cucumber and other vegetables. Sodium tripolyphosphate may act as a cross-linker for stabilizing the nanoparticle polymers in nanoparticle formations in coating treatments to prolong the shelf-life and achieve an excellent quality [44].

\section{Conclusions}

Chitosan/nano-titanium oxide crystals/sodium tripolyphosphate films can be used for the extension of shelf-life by maintaining some quality parameters such as color index profile, skin toughness, crispness index, reducing sugars, and total sugars, with the addition of the antimicrobial contamination against Salmonella spp. during the chilling condition for 21 days at $10^{\circ} \mathrm{C}$. Using sodium tripolyphosphate as a crosslinker, is needed for nanotechnology applications in the food packaging industry.

Author Contributions: Methodology, M.H., R.S., E.A., A.A. (Amal Alyamani), G.A., H.A., N.B., S.A., A.A. (Abeer Almasoudi), N.M. and A.A.M.A.-M. writing-review and editing, M.H., R.S., N.K., A.I. and M.C. All authors have read and agreed to the published version of the manuscript.

Funding: This research received no external funding.

Institutional Review Board Statement: Not applicable.

Informed Consent Statement: Not applicable.

Data Availability Statement: Available upon request from the corresponding author.

Acknowledgments: Taif University Researchers Supporting Project Number (TURSP-2020/140), Taif University, Taif, Saudi Arabia. Princess Nourah bint Abdulrahman University Researchers Supporting Project Number (PNURSP2022R43), Princess Nourah bint Abdulrahman University, Riyadh, Saudi Arabia. In addition, the authors thank Prince Sattam Bin Abdulaziz University, Al-Kharj for their scientific contributions.

Conflicts of Interest: The authors declared no conflict of interest.

\section{References}

1. Gutiérrez-Pacheco, M.M.; Ortega-Ramírez, L.A.; Silva-Espinoza, B.A.; Cruz-Valenzuela, M.R.; González-Aguilar, G.A.; LizardiMendoza, J.; Miranda, R.; Ayala-Zavala, J.F. Individual and Combined Coatings of Chitosan and Carnauba Wax with Oregano Essential Oil to Avoid Water Loss and Microbial Decay of Fresh Cucumber. Coatings 2020, 10, 614. [CrossRef]

2. Saad, M.M. Effect of Some Postharvest Treatments on Reducing Chilling Injury of Cucumber Fruits during Cold Storage. Ann. Agric. Sci. Moshtohor 2019, 57, 455-468. [CrossRef]

3. Nasef, I.N. Short hot water as safe treatment induces chilling tolerance and antioxidant enzymes, prevents decay and maintains quality of cold-stored cucumbers. Postharvest Biol. Technol. 2018, 138, 1-10. [CrossRef] 
4. Olawuyi, I.F.; Lee, W. Influence of chitosan coating and packaging materials on the quality characteristics of fresh-cut cucumber. Korean J. Food Preserv. 2019, 26, 371-380. [CrossRef]

5. Elhake, A.H.; Benajiba, N.; Koko, M.Y.; Khojah, E.; Rok, A. DPPH, FRAP and TAEC Assays with Postharvest Cabbage (Brassica oleracea) Parameters During the Packaging Process. Pak. J. Biol. Sci. 2021, 24, 182-187. [CrossRef]

6. Rokayya, S.; Khojah, E. Physical-mechanical Estimation of Pepper (Capsicum annuum L.) Fruit Varieties. J. Northeast Agric. Univ. 2016, 23, 61-69. [CrossRef]

7. Vivek, K.; Singh, S.S.; Sasikumar, R.; Sami, R. Consumer preference study on combined ultrasound and sodium hypochlorite treated freshcut kiwifruits coated with chitosan using the fuzzy logic approach: Sensory study of chitosan coated fresh-cut kiwi fruits. J. Microbiol. Biotechnol. Food Sci. 2021, 11, e4054. [CrossRef]

8. Eldib, R. Application of Nano-coating and Chitosan Combination Films on Cantaloupe Preservation. Pak. J. Biol. Sci. 2020, 23, 1037-1043. [CrossRef]

9. Eldib, R.; Khojah, E.; Elhakem, A.; Benajiba, N.; Helal, M. Chitosan, Nisin, Silicon Dioxide Nanoparticles Coating Films Effects on Blueberry (Vaccinium myrtillus) Quality. Coatings 2020, 10, 962. [CrossRef]

10. Zhao, Y.; Mingfeng, C.; Aiqiang, C.; Na, Z.; Songsong, Z. Analysis about Heat Transfer of Vegetables during Cold Shock Treatment and Preservation Quality after Storage. Int. J. Food Eng. 2017, 13, 20150369. [CrossRef]

11. Esmaeili, Y.; Zamindar, N.; Paidari, S.; Ibrahim, S.A.; MohammadiNafchi, A. The synergistic effects of aloe vera gel and modified atmosphere packaging on the quality of strawberry fruit. J. Food Processing Preserv. 2021, 45, e16003. [CrossRef]

12. Jafarzadeh, S.; MohammadiNafchi, A.; Salehabadi, A.; Oladzad-abbasabadi, N.; Jafari, S.M. Application of bio-nanocomposite films and edible coatings for extending the shelf life of fresh fruits and vegetables. Adv. Colloid Interface Sci. 2021, $291,102405$. [CrossRef]

13. Paidari, S.; Tahergorabi, R.; Anari, E.S.; Nafchi, A.M.; Zamindar, N.; Goli, M. Migration of Various Nanoparticles into Food Samples: A Review. Foods 2021, 10, 2114. [CrossRef]

14. Sami, R.; Soltane, S.; Helal, M. Microscopic Image Segmentation and Morphological Characterization of Novel Chitosan/Silica Nanoparticle/Nisin Films Using Antimicrobial Technique for Blueberry Preservation. Membranes 2021, 11, 303. [CrossRef] [PubMed]

15. Oladzadabbasabadi, N.; Nafchi, A.M.; Ariffin, F.; Wijekoon, M.M.; Al-Hassan, A.A.; Dheyab, M.A.; Ghasemlou, M. Recent advances in extraction, modification, and application of chitosan in packaging industry. Carbohydr. Polym. 2022, 277, 118876. [CrossRef]

16. Sami, R.; Almatrafi, M.; Elhakem, A.; Alharbi, M.; Benajiba, N.; Helal, M. Effect of Nano Silicon Dioxide Coating Films on the Quality Characteristics of Fresh-Cut Cantaloupe. Membranes 2021, 11, 140. [CrossRef] [PubMed]

17. Sami, R.; Elhakem, A.; Alharbi, M.; Benajiba, N.; Fikry, M.; Helal, M. The combined effect of coating treatments to nisin, nano-silica, and chitosan on oxidation processes of stored button mushrooms at $4{ }^{\circ} \mathrm{C}$. Sci. Rep. 2021, 11, 6031. [CrossRef] [PubMed]

18. Li, J.; Li, Q.; Lei, X.; Tian, W.; Cao, J.; Jiang, W.; Wang, M. Effects of Wax Coating on the Moisture Loss of Cucumbers at Different Storage Temperatures. J. Food Qual. 2018, 2018, 9351821. [CrossRef]

19. Sami, R.; Elhakem, A.; Alharbi, M.; Benajiba, N.; Almatrafi, M.; Jing, J.; Helal, M. Effect of Titanium Dioxide Nanocomposite Material and Antimicrobial Agents on Mushrooms Shelf-Life Preservation. Processes 2020, 8, 1632. [CrossRef]

20. Khojah, E.; Sami, R.; Helal, M.; Elhakem, A.; Benajiba, N.; Alharbi, M.; Alkaltham, M.S. Effect of Coatings Using Titanium Dioxide Nanoparticles and Chitosan Films on Oxidation during Storage on White Button Mushroom. Crystals 2021, 11, 603. [CrossRef]

21. Rokayya, S.; Jia, F.; Li, Y.; Nie, X.; Xu, J.; Han, R.; Yu, H.; Amanullah, S.; Almatrafi, M.M.; Helal, M. Application of nano-titanum dioxide coating on fresh Highbush blueberries shelf life stored under ambient temperature. LWT 2021, 137, 110422. [CrossRef]

22. Khafar, E.A.A.; Zidan, N.S.; Aboul-Anean, H.E.D. The Effect of Nano Materials on Edible Coating and Films' Improvement. Int. J. Pharm. Res. Allied Sci. 2018, 7, 20-41.

23. Khojah, E.; Sami, R.; Helal, M.; Elhakem, A.; Benajiba, N.; Alkaltham, M.S.; Salamatullah, A.M. Postharvest Physicochemical Properties and Fungal Populations of Treated Cucumber with Sodium Tripolyphosphate/Titanium Dioxide Nanoparticles during Storage. Coatings 2021, 11, 613. [CrossRef]

24. Fikry, M.; Khalifa, I.; Sami, R.; Khojah, E.; Ismail, K.A.; Dabbour, M. Optimization of the Frying Temperature and Time for Preparation of Healthy Falafel Using Air Frying Technology. Foods 2021, 10, 2567. [CrossRef] [PubMed]

25. Dabbour, M.; Sami, R.; Mintah, B.K.; He, R.; Wahia, H.; Khojah, E.; Petkoska, A.T.; Fikry, M. Effect of Drying Techniques on the Physical, Functional, and Rheological Attributes of Isolated Sunflower Protein and Its Hydrolysate. Processes 2022, 10, 13. [CrossRef]

26. Mohamed, M.H.M.; Sami, R.; Al-Mushhin, A.A.M.; Ali, M.M.E.; El-Desouky, H.S.; Ismail, K.A.; Khalil, R.; Zewail, R.M.Y. Impacts of Effective Microorganisms, Compost Tea, Fulvic Acid, Yeast Extract, and Foliar Spray with Seaweed Extract on Sweet Pepper Plants under Greenhouse Conditions. Plants 2021, 10, 1927. [CrossRef]

27. El-Gioushy, S.F.; Sami, R.; Al-Mushhin, A.A.M.; Abou El-Ghit, H.M.; Gawish, M.S.; Ismail, K.A.; Zewail, R.M.Y. Foliar Application of $\mathrm{ZnSO}_{4}$ and $\mathrm{CuSO}_{4}$ Affects the Growth, Productivity, and Fruit Quality of Washington Navel Orange Trees (Citrus sinensis L.) Osbeck. Horticulturae 2021, 7, 233. [CrossRef]

28. Sami, R.; Elhakem, A.; Alharbi, M.; Benajiba, N.; Almatrafi, M.; Helal, M. Nutritional Values of Onion Bulbs with Some Essential Structural Parameters for Packaging Process. Appl. Sci. 2021, 11, 2317. [CrossRef] 
29. Zapotoczny, P.; Markowski, M. Influence of hypobaric storage on the quality of greenhouse cucumbers. Bulg. J. Agric. Sci. 2014, 20, 1418-1424.

30. Kanno, T.; Kamimura, S. Measuring textural characteristics and varietal differences of skin toughness and flesh firmness in the cucumber fruit. Bull. Veg. Ornam. Crops Res. Stn. Ser. B Morioka 1978, 2, $25-42$.

31. Morishita, M.; Sugiyama, K.; Saito, T.; Sakata, Y. An improved evaluation method for screening and selecting powdery mildew resistant cultivars and lines of cucumber (Cucumissativus L.). J. Jpn. Soc. Hortic. Sci. 2002, 71, 94-100. [CrossRef]

32. Sami, R.; Elhakem, A.; Almushhin, A.; Alharbi, M.; Almatrafi, M.; Benajiba, N.; Fikry, M.; Helal, M. Enhancement in physicochemical parameters and microbial populations of mushrooms as influenced by nano-coating treatments. Sci. Rep. 2021, 11, 7915. [CrossRef] [PubMed]

33. Helal, M.; Sami, R.; Khojah, E.; Elhakem, A.; Benajiba, N.; Al-Mushhin, A.A.M.; Fouda, N. Evaluating the coating process of titanium dioxide nanoparticles and sodium tripolyphosphate on cucumbers under chilling condition to extend the shelf-life. Sci. Rep. 2021, 11, 1-8. [CrossRef]

34. Meng, X.; Zhang, M.; Zhan, Z.; Adhikari, B. Changes in Quality Characteristics of Fresh-cut Cucumbers as Affected by Pressurized Argon Treatment. Food Bioprocess Technol. 2014, 7, 693-701. [CrossRef]

35. Aboul-Anean, H.E.-D.; Aly, H.H. Effect of some edible coatings on storability of organic cucumber fruit. Egypt. J. Agric. Res. 2015, 93, 1013-1029.

36. Mohammadi, A.; Hashemi, M.; Hosseini, S.M. Postharvest treatment of nanochitosan-based coating loaded with Zataria multiflora essential oil improves antioxidant activity and extends shelf-life of cucumber. Innov. Food Sci. Emerg. Technol. 2016, 33, 580-588. [CrossRef]

37. Dong, F.; Li, S.; Jin, C.; Liu, Z.; Zhu, K.; Zou, H.; Wang, X. Effect of nanocellulose/chitosan composite coatings on cucumber quality and shelf life. Toxicol. Environ. Chem. 2016, 98, 450-461. [CrossRef]

38. Sami, R.; Khojah, E.; Helal, M.; Elhakem, A.; Benajiba, N.; Al-Mushhin, A.A.M.; Alkaltham, M.S.; Salamatullah, A.M.; Vivek, K.; Fouda, N. Effects of Coating by Chitosan, $\mathrm{TiO}_{2}$ Nanoparticles, and Sodium Tripolyphosphate as Crosslinker on Stored Cucumber Fruits. J. Biobased Mater. Bioenergy 2021, 15, 598-605. [CrossRef]

39. Ozer, M.H.; Akbudak, B.; Uylaser, V.; Tamer, E. The effect of controlled atmosphere storage on pickle production from pickling cucumbers cv. 'Troy'. Eur. Food Res. Technol. 2006, 222, 118-129. [CrossRef]

40. Nakamachi, A.; Yoshikawa, M.; Kasai, M.; Hatae, K. Change and distribution of taste components during the storage of cucumbers. J. Cook. Sci. Jpn. 2002, 35, 234-241.

41. Hara-Kudo, Y.; Konuma, H.; Kamata, Y.; Miyahara, M.; Takatori, K.; Onoue, Y.; Sugita-Konishi, Y.; Ohnishi, T. Prevalence of the main food-borne pathogens in retail food under the national food surveillance system in Japan. Food Addit. Contam. Part A 2013, 30, 1450-1458. [CrossRef] [PubMed]

42. Kim, J.H.; Yoo, J.G.; Ham, J.S.; Oh, M.H. Direct Detection of Escherichia coli, Staphylococcus aureus, and Salmonella spp. in Animalderived Foods Using a Magnetic Bead-based Immunoassay. Korean J. Food Sci. Anim. Resour. 2018, 38, 727-736. [CrossRef] [PubMed]

43. Ha, J.; Park, E.; Kim, J.-S.; Lee, S.; Kim, S.; Lee, J.; Choi, Y.; Yoon, Y.; Oh, H.; Kim, Y.; et al. Prevalence of Salmonella in cucumbers, antibiotic and acid resistances and description of the kinetic behavior with dynamic model during storage. J. Food Saf. 2020, 40, e12760. [CrossRef]

44. Shah, B.R.; Li, Y.; Jin, W.; An, Y.; He, L.; Li, Z.; Xu, W.; Li, B. Preparation and optimization of Pickering emulsion stabilized by chitosan-tripolyphosphate nanoparticles for curcumin encapsulation. Food Hydrocoll. 2016, 52, 369-377. [CrossRef] 